\title{
水利水电工程造价影响因素分析及控制造价的措施
}

\author{
李远洋 \\ 大连瑞倡建设工程有限公司 \\ DOI:10.32629/hwr.v4i5.2980
}

[摘 要] 企业要想实现长远发展目标, 必须加大对工程造价控制的重视度,节约投资成本,拓展经济效益的增长空间。但水利水电工程造价的影 响因素较多,而且这些影响因素制约了企业的良好发展。为此,本文围绕水利水电工程造价影响因素与造价控制手段展开系统探究。

[关键词] 水利水电工程; 造价影响因素; 控制造价措施

市场经济的繁荣发展, 为水利水电行业提供了广阔的发展前景。同时 也进一步激化了水利水电行业的市场竞争。企业要想扩大自身的竞争优势, 就必须全面分析工程造价影响因素, 采取切实可行的工程造价控制措施, 以实现工程项目经济效益与社会效益的最大化。

\section{1 水利水电工程造价控制的积极意义}

水利水电工程施工全过程离不开造价管理工作。科学合理的造价管理, 就是对各个施工阶段进行监督控制, 避免某一环节造价错误, 延误工期, 增 加成本。工程造价管理工作涉及面较广, 且各部门的工作任务与目标也各 不相同。只有促进各部门的协调配合, 才能优化资金分配, 实现经济效益的 最大化。

\section{2 水利水电工程造价影响因素}

2. 1 设计因素

工程设计不仅是水利水电工程施工初期阶段的重点工作内容, 同时也 与后续施工存在紧密联系。工程设计方面的投资成本约占整体工程造价的 $5 \%$, 但设计方案中的内容却占整体工程造价的 $90 \%$ 以上。这些内容具体包括 施工流程、施工工艺、施工材料与施工设备等。无论是哪一项内容发生改 变, 都会影响工程造价。

\section{2 材料与设备费用影响因素}

在水利水电工程施工中, 施工材料与机械设备的支出占整体工程造价 的绝对比重。为此, 全面控制施工材料与机械设备费用显得尤为重要。然 而, 在水利水电工程实际施工中, 经常出现施工材料与机械设备费用超支 的情况, 导致工程造价超过预算范围。此外, 部分水利水电工程对施工材料 与机械设备费用的控制力度不足。尽管材料与设备的质量符合标准要求, 但造价过高, 无法满足性价比最优化的基本要求。若重新购置材料与设备, 必定会造成资源限制与成本浪费, 增加工程造价。

\section{3 人为影响因素}

无论是水利水电工程施工, 还是水利水电工程管理, 都需要依靠人力 来完成。尽管现代化机械设备被广泛应用到水利水电工程施工中, 但机械 设备的操控仍无法完全脱离人工干预, 而这也使得工程造价极易受到人为 因素的影响。只有施工人员与管理人员具备较强的工程造价控制意识, 才 能在规定期限内完成施工任务, 将工程造价控制在预算范围内。然而当前 大多数工作人员成本控制意识淡薄, 设备浪费与材料损耗临近限值, 甚至 超过限值, 工程造价持续上升, 远离预期效益目标。

\section{3 加强水利水电工程造价控制的具体策略}

3.1 优化完善工程设计方案

对水利水电工程项目来说, 工程设计在很大程度上影响着工程造价。 为此, 必须制定科学合理的设计方案。在工程设计时, 一方面, 要充分考虑 工程项目经济性, 确保工程预算在可接受范围内。另一方面, 考虑设计方案 的合理性和可执行性。若设计方案可执行性出现问题, 必须第一时间予以
修改。设计人员需深入施工场区进行环境勘察, 全面了解施工场区环境特 征, 注重设计方案的完整性、合理性与可执行性。设计方案编制完成后, 设计部门应全面分析设计方案的优劣性, 在未正式施工前, 改正方案内容, 为压缩工程造价奠定坚实基础。

3. 2 加强材料与设备费用管理

首先, 明确材料采购标准, 严格按照采购标准进行采购。在采购过程中, 综合对比材料型号、性能与质量, 严格检查供应商的运营资质与材料质量 证明文件, 在保证材料质量的基础上, 将成本控制在合理范围内。其次, 明 确设备租赁与采购标准。针对使用频率较低的机械设备, 采取短期租赁的 方式替代垄断购置, 最大限度地压缩成本。在此基础上, 加强材料运输管 理。材料运输过程中, 不可避免的会出现损害。为此, 相关人员要采取切实 可行的防护措施, 尽可能的避免材料损害, 减轻损害程度。最后, 高效合理 地应用新型材料与新型工艺技术, 如可回收利用材料等。由此, 减轻材料损 耗, 提高施工效率, 缩短工程周期, 降低工程造价。

3. 3强化工作人员综合素质

为加强水利水电工程造价控制落实效果, 完善从业人员的教育培训至 关重要。一方面, 要增强从业人员的责任意识与安全防范意识, 提升从业人 员的专业技能水平, 更好的完成工程造价控制工作。另一方面, 引导从业人 员明确岗位责任制度, 激发从业人员的主观能动性。在培训期间, 开展阶段 性考核, 检验培训成果。

例如, 可全面推行人性化奖惩制度, 针对工作表现突出的员工给予适 当的物质奖励, 提供岗位晋升机会或带薪培训机会; 针对工作态度散漫, 缺乏责任心的员工, 给予通报批评。由此, 充分调动全体员工的工作积极性, 确保工程造价控制工作的高度落实。

\section{4 结束语}

综上所述, 水利水电工程造价控制是一项综合性、系统性与复杂性较 强的工作。建设企业需加大对工程造价控制工作的重视力度, 从人员、材 料设备、设计方案入手, 加强造价管控, 以保障工程项目的质量安全与综合 效益, 达到可持续发展战略目标。

[参考文献]

[1]万勇军.工程造价在水利水电工程中的重要作用 [J].四川建 材,2018,44(10):220+223.

[2]张弼.水利水电工程施工造价管理与控制探讨 [ J]. 工程技术研 究,2020,5(04):204-205.

[3]王明德.浅析水利水电工程施工现场安全管理 [J]. 智能城 市,2019,5(23):88-89.

[4]黄志富.水利水电工程管理及施工质量控制的相关问题探讨 [J].四 川水泥,2019,(11):216. 